SELÇUK ÜNIVERSITESI

HUKUK FAKÜLTESI DERGİSI

Selçuk Law Review

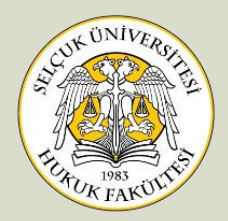

Araştırma Makalesi Research Article

Gönderim | Received: 31.03 .2020

Kabul | Accepted: 24.04.2020

doi) $10.15337 /$ suhfd. 712357

\title{
RUSYA FEDERASYONU CEZA HUKUKUNDA ÖLÜM CEZASI
}

\author{
Dr. Öğr. Üyesi Emin HÜSEYINOĞLU*
}

Öz

Rusya Federasyonu Ceza Kanunu'nun 59/1. maddesine göre “Ölüm cezası istisnai ceza tedbiri olarak sadece hayata yönelmiş nitelikli ă̆ır suçlara düzenlenebilir.

Avrupa İnsan Hakları Sözleşmesi'ne Ek 6 Numaralı Protokol ile savaş ve yakın savaş tehdidi durumları dışında ölüm cezası kaldırılmıştır. Rusya Federasyonu 28.02.1996 tarihinde Avrupa Konseyine üye olmuş ve 16.04.1997 tarihinde $6 \mathrm{Nu}$ maralı Protokolü imzalamıştır. 16.05.1996 tarihinde ise Rusya'nın Avrupa Konseyine Katılımıyla Bağlantılı Olarak Ölüm Cezası Uygulamasının Aşamalı Olarak Azaltılması Hakkında Devlet Başkanı kararnamesiyle moratoryum ilan edilmiştir. Bununla birlikte, 6 Numaralı Protokol Federal Meclis tarafından bugüne kadar onaylanmamıştır.

Rusya Federasyonu Anayasa Mahkemesi 19.11.2009 tarihinde Rusya Federasyonu Avrupa Konseyi üyeliğinden ayrılmadığı sürece hiçbir mahkemenin ölüm cezası veremeyeceğine karar vermiştir.

\section{Anahtar Kelimeler}

Ölüm Cezası • Rusya Federasyonu • Moratoryum • Ceza Kanunu • Suç

* Dr. Öğr. Üyesi, Karabük Üniversitesi, İktisadi ve İdari Bilimler Fakültesi, Siyaset Bilimi ve Kamu Yönetimi Bölümü, Karabük, Türkiye | Asst. Prof., Karabük University, Faculty of Economics and Administrative Sciences, Department of Political Science and Public Administration, Karabük, Turkey.

๑ eminhuseyinoglu@gmail.com • ORCID 0000-0002-4196-2295

Atıf Şekli | Cite As: HÜSEYİNOĞLU Emin, “Rusya Federasyonu Ceza Hukukunda Ölüm Cezası", SÜHFD., C. 28, S. 2, 2020, s. 427-444.

Intihal | Plagiarism: Bu makale intihal programında taranmış ve en az iki hakem incelemesinden geçmiştir. I This article has been scanned via a plagiarism software and reviewed by at least two referees. 


\title{
CAPITAL PUNISHMENT IN THE CRIMINAL CODE OF THE RUSSIAN FEDERATION
}

\begin{abstract}
According to the Article 59/1 of the Criminal Code of the Russian Federation: "Capital punishment, as an exclusive penalty, may be imposed only for especially grave crimes encroaching on human life".

With the Annex Protocol No.6 to the European Convention on Human Rights, the capital punishment has been abolished except for war and melee threads. The Russian Federation became a member of the Council of Europe on 28.02.1996 and signed Protocol No.6 on 16.04.1997. On 16.05.1996, the Moratorium was announced with the President's decree on the Progressive Reduction of the Capital Punishment in conjunction with the participation of Russia in the Council of Europe. However, Protocol No.6 has not been ratified by the Federal Assembly until today.
\end{abstract}

On 19.11.2009, the Constitution Court was decided to no court cannot give would be able to impose a capital punishment unless the Russian Federation leaves membership of the Council of Europe.

\section{Key Words}

Capital Punishment • Russian Federation • Moratorium • Criminal Law • Crime

\section{GíRiş}

Ölüm cezası, ceza hukukunda üzerinde çok tartışma bulunan konulardan biridir. Ölüm cezasına karşı olan görüşler; bu ceza türünün meşru insan öldürme olduğu ve devletin katil olamayacağını, ölüm cezasında adli hataların telafisinin imkansız olduğunu, ölüm cezasının caydırıcılık ve suç oranının azaltılmasında etkisinin bulunmadığını, bedensel ceza olması sebebiyle hümanizm ilkesine aykırı olduğu, cezanın amacının suçluyu ıslah edip topluma yeniden kazandırmak olduğunu ileri sürmektedirler.

Ölüm cezasından yana olan görüşler ise; ölüm cezası yerine uygulanan müebbet hapis cezasinın zamanla siyasi nedenlerle affedilmesi nedeniyle etkili olmadığını, ölüm cezasının toplumda korku yaratması nedeniyle caydırıcı olup suç oranını azalttığını, yapılan referandumların 
toplumun çoğunluğunun ölüm cezasından yana olduğunu ileri sürmektedirler ${ }^{1}$.

Ölüm cezasının caydırıcı olup suçları önlediği konusunda kesin bir şey söylemek mümkün değildir. Ölüm cezasını kaldıran ülkelerde suç oranının artmasını, bu cezanın kaldırılmasına bağlamak kusurlu bir yaklaşımdır. Çünkü suç oranının artmasına neden olan farklı etmenler bulunmaktadır².

Son dönemde ceza hukukçularının büyük çoğunluğunun ölüm cezasına karşı olduğu görülmektedir. Buna bağlı olarak modern ülkelerin çoğunda ölüm cezası kaldırılmış veya uygulama alanı aşırı derece sınırlandirılmıştır.

\section{AVRUPA İNSAN HAKLARI SÖZLEŞMESI'NE EK 6 VE 13 NU- MARALI PROTOKOL}

Avrupa İnsan Hakları Sözleşmesi'ne Ek 6 Numaralı Protokol'ün 1. ve 2. maddelerinde barış zamanı ölüm cezasının uygulanması yasaklamıştır. 6 Numaralı Protokolün “Ölüm Cezasının Kaldırılması” başlıklı 1. maddesine göre, "Ölüm cezası kaldırılmıştır. Hiç kimse bu cezaya çarptırılamaz ve idam edilemez". Protokolün "Savaş Zamanında Ölüm Cezası" başlıklı 2. maddesine göre ise "Bir Devlet, savaş zamanında veya yakın savaş tehdidi durumlarında işlenen eylemler için yasalarında ölüm cezasına ilişkin hüküm öngörebilir; böyle bir ceza, ancak, yasada belirtilen durumlarda ve yasa hükümlerine uygun olarak uygulanabilir. Bu Devlet, sözkonusu yasaların ilgili hükümlerini Avrupa Konseyi Genel Sekreteri'ne bildirecektir".

Avrupa İnsan Hakları Sözleşmesi'ne Ek 13 Numaralı Protokol ise savaş durumu dahil olmak üzere ölüm cezasını tüm koşullarda ortadan kaldırmıştır. 13 Numaralı Protokol'ün "Ölüm Cezasının Kaldırılması" başlıklı 1. maddesine göre, “Ölüm cezası kaldırılmıştır. Hiç kimse bu cezaya çarptırllamaz ve idam edilemez"

1 ÖNDER, Ayhan, Ceza Hukuku Dersleri, Filiz Kitabevi, İstanbul 1992, s.492.

2 DÖNMEZER, Sulhi / ERMAN, Sahir, Nazari ve Tatbiki Ceza Hukuku, Genel Kısım, Cilt II, 11. Bası, Beta Yayınları, İstanbul 1999, s.606.

36 Numaralı Protokol 15.1.2003 tarihinde Türkiye tarafından imzalanmış ve 26.6.2003 tarih ve 4913 sayılı Kanunla TBMM tarafından onaylanmıştır. 13 Numaralı Protokol ise 9.1.2004 tarihinde Türkiye tarafından imzalanmış ve 6.10.2005 tarih ve 5409 sayılı Kanunla TBMM tarafından onaylanmıştır. Buna bağlı olarak 7.5.2004 tarih ve 5170 
Rusya Federasyonu 28.02.1996 tarihinde Avrupa Konseyine üye olmuştur ${ }^{4}$. Avrupa Konseyine üye olan Rusya Federasyonu 6 Numaralı Protokolü en geç bir sene içerisinde imzalama, üç sene içerisinde onaylama ve ölüm cezalarının infazı konusunda moratoryum (erteleme) uygulama taahhüdünde bulunmuştur ${ }^{5}$.

\section{EKIMM DEVRIMI DÖNEMİ}

Rus hukuk tarihine bakıldığında, ölüm cezasının zaman zaman kısa süreliğine kaldırıldığı, fakat her defasında geri getirildiği görülmektedir.

Sovyet iktidarında ilk başlarda ölüm cezaları azaltılmış, fakat daha sonraları çok hızlı bir şekilde artış göstermiştir'. 1917 Ekim Devrimi sonrasında 12.03.1917 tarihinde geçici hükümet kararıla ölüm cezası kaldırılmış, fakat kısa süre sonra 12.07.1917 tarihinde geri kabul edilmiştir7.

26.10.1917 tarihinde İkinci Sovyet Kongresi tarafından ölüm cezası tekrar kaldırılmış, fakat iç savaşın başlamasıyla birlikte 21.02.1918 tarihinde geri kabul edilmiştir8. Devrim mahkemeleri tarafından il ölüm cezası 21.06.1918 tarihinde eski deniz kuvvetleri komutanı olan Aleksey Şastnıy hakkında verilmiştir 9 .

Ölüm cezası, "kurşuna dizilme" adı altında, 1919 tarihli Rusya Sovyet Federatif Sosyalist Cumhuriyeti Ceza Hukukunun Rehber İlkeleri'nde de geçici, istisnai ve olağanüstü tedbir olarak yer almıştır.

sayılı Kanunla Türkiye Cumhuriyeti Anayasası'nın 38. maddesine “Ölüm cezası ve genel müsadere cezası verilemez" hükmü eklenmiştir.

4 Rossiya v Sovete Evrop1 (Rusya Avrupa Konseyi'nde), https://www.mid.ru/rossia-vsovete-evropy, Erişim Tarihi: 29.3.2020.

5 PETRUHIN, İgor, “Pravo Na Jizn i Smertnaya Kazn (Yaşam Hakkı ve Ölüm Cezası)”, Obşestvenniye Nauki i Sovremennost, No: 5, 1999, http://ecsocman.hse.ru/data/423/343/1217/008pETRUHIN.pdf, Erişim Tarihi: 9.1.2020, s.84.

6 PETRUHIN, http://ecsocman.hse.ru/data/423/343/1217/008pETRUHIN.pdf, s.85.

7 NAUMOV, Anatoliy, Rusya Cinayet Hüququ, Ümumi Hisse, (Tercüme: Qurbanov H.), Qanun Neşriyyatı, Bakı 1998, s.448.

$8 \quad$ KOZAÇENKO, İvan / NEZNAMOVA, Zinaida (Ed.), Ugolovnoye Pravo (Ceza Hukuku), Obşaya Çast (Genel Kısım), İzdatelstvo İnfra.M-Norma, Moskva 1997, s.353; PETRUHIN, http://ecsocman.hse.ru/data/423/343/1217/008pETRUHIN.pdf, s.83.

9 KOZAÇENKO / NEZNAMOVA (Ed.), s.353. 
17.01.1920 tarihinde ölüm cezası tekrar kaldırılmışs ${ }^{10}$, fakat çok kısa süre sonra 11.05.1920 tarihinde geri kabul edilmiştir ${ }^{11}$.

\section{1922 TARİHLI RUSYA SOVYET FEDERATIF SOSYALİST CUMHURIYYETI CEZA KANUNU}

Ölüm cezası, 1.6.1922 tarihinde yürürlüğe giren 1922 tarihli Rusya Sovyet Federatif Sosyalist Cumhuriyeti Ceza Kanunu'nda (RSFSCCK) da yer almıştır.

Bu Kanunun 33. maddesine göre, "Yüksek Mahkeme, il mahkemeleri ve her türlü devrim mahkemelerinde bulunan davalarda, Rusya Merkezi Yürütme Komitesi tarafindan kaldırlıncaya kadar, bu Kanunun maddelerinde belirtilen hallerde en yüksek ceza tedbiri olan ölüm cezası uygulanır. Suç işlendiği sırada on sekiz yaşını doldurmamış olanlar ve hamile kadınlar hakkında ölüm cezasına hükmedilemez".

\section{1926 TARIHLI RUSYA SOVYET FEDERATIF SOSYALİST CUMHURIYYTI CEZA KANUNU}

Ölüm cezası, 1.1.1927 tarihinde yürürlüğe giren 1926 tarihli RSFSCCK' da da benzer şekilde düzenlenmiştir. Bu Kanunun 21. maddesine göre, "Sovyet iktidarn ve Sovyet düzeninin ilkelerini tehdit eden daha ă̆ır suç türleri ile mücadele için SSCB Merkezi Yürütme Komitesi tarafindan kaldrulıncaya kadar, bu Kanunun maddelerinde özel olarak belirtilen hallerde istisnai tedbir olarak işçi devletini korumak amacıyla ölüm cezası uygulanır". Kanunun 22. maddesine göre ise "Suç işlendiği sırada on sekiz yaşını doldurmamış olanlar ve hamile kadınlar hakkında ölüm cezasına hükmedilemez".

Ölüm cezasının kaldırılmasına yönelik son düzenleme, 26.05.1947 tarihli Sovyet Sosyalist Cumhuriyetler Birliği (SSCB) Yüksek Sovyet Başkanlığının Ölüm Cezasının Kaldırılması Hakkında Kararname ile gerçekleşmiştir. Bu Kararnamede barış zamanında işlenen suçlar bakımından ölüm cezası 25 sene ıslah-çalışma kampında hapis cezasına çevrilmiştir ${ }^{12}$.

\footnotetext{
10 KOZAÇENKO / NEZNAMOVA (Ed.), s.353-354.

11 PETRUHIN, http://ecsocman.hse.ru/data/423/343/1217/008pETRUHIN.pdf, s.83.

12 VASİLEV, Aleksey, “Smernaya Kazn v Rosii: Vısşaya, İsklyuçitelnaya Mera Nakazaniya, Ustraşeniya ili Politika? (Rusya'da Ölüm Cezası: Yüksek, İstisnai Ceza Tedbiri, Gözdağı mi? Siyaset mi?)", No: 4, 2013, https://nbpublish.com/library_read_article.php?id=674, Erişim Tarihi: 22.02 .2020 .
} 
Fakat SSCB Yüksek Sovyet Başkanlığının 12.01.1950 tarihli Kararnamesiyle vatan hainliği, casusluk ve sabotaj suçları bakımından ölüm cezası geri getirilmiştir ${ }^{13}$. SSCB Yüksek Sovyet Başkanlığının 30.04.1954 tarihli Kararnamesiyle ise ölüm cezası nitelikli insan öldürme suçu bakımından da kabul edilmiş ${ }^{14}$ ve zamanla ölüm cezasını gerektiren suçların sayısı artırılmıştır ${ }^{15}$.

26.05.1947 ile 12.01.1950 tarihleri arasında ölüm cezasının tam olarak kaldırıldığını söylemek pek mümkün değildir. Çünkü bu dönemde SSCB Milli Savunma Bakanlığının devrim karşıtı suçlara ölüm cezası verilebileceği konusunda gizli talimatı bulunmaktayd $\mathbf{1}^{16}$.

Görüldügüü üzere Sovyet iktidarı döneminde ölüm cezası birkaç kez kaldırılmasına rağmen, her defasında savaş ve "vatan hainleri" ile mücadele gerekçeleriyle geri getirilmiştir ${ }^{17}$.

Ölüm cezası özellikle Stalin döneminde devrim karşıtı suçlar karşılığında çok sık uygulanmıştır. Resmi kayıtlara göre, 1921 ile 1954 tarihleri arasında 643.000 kişi idam edilmiştir. Gerçek rakamların ise 1.000 .000 civarı olduğu sanılmaktadır ${ }^{18}$.

13 KOZAÇENKO, İvan / NOVOSELOV, Gennadiy, Ulolovnoye Pravo (Ceza Hukuku), Obşaya Çast (Genel Kısım), İzdatelstvo Yurayt, Moskva 2018, s.255.

14 POBEYGALO, Eduard, “O Prestupnosti v Rosii i Problema Smertnoy Kazni (Rusya'da Suç ve Ölüm Cezası Problemi Hakkında)", Evraziyskiy Forum, No: 1 (2), 2010, https://cyberleninka.ru/article/n/o-prestupnosti-v-rossii-i-probleme-smertnoykazni-1, Erişim Tarihi: 12.2.2020, s.30; KOZAÇENKO / NOVOSELOV, s.255.

15 VASILEV, https://nbpublish.com/library_read_article.php?id=674.

16 VASİLEV, https://nbpublish.com/library_read_article.php?id=674; PETRUHIN, http://ecsocman.hse.ru/data/423/343/ 1217/ 008pETRUHIN.pdf, s.83.

17 VASILEV, https://nbpublish.com/library_read_article.php?id=674.

18 VASILEVV, https://nbpublish.com/library_read_article.php?id=674; KGB'nin 14.3.1990 tarihli verilerine göre, 1921-1953 yılları arasında 3.7 milyon kişi mahkeme kararıyla veya mahkeme kararı olmaksızın devrim karşıtı suçlardan mahkum olmuş ve bunlardan 790.000 kişi idam edilmiştir (KUZNESOVA, Ninel / TYAJKOVA, İrina (Ed.), Kurs Ugolovnogo Prava (Ceza Hukuku Dersleri), Obşaya Çast (Genel Kısım), Uçeniya o Prestuplenii (Suç Hakkında), Tom 1 (1. Cilt), İzdatelstvo Zersalo, Moskva 2002, s.47). 


\section{1960 TARIHLI RUSYA SOVYET FEDERATIF SOSYALİST CUMHURIYETI CEZA KANUNU}

Ölüm cezası, 1.1.1961 tarihinde yürürlüğe giren 1960 tarihli RSFSCCK' da da yer almıştır. Bu Kanunun "İstisnai Ceza Tedbiri / Ölüm Cezası" başlıklı 23. maddesine göre, "Bu Kanunun belirttiği hallerde, nitelikli ă̆ır suçlar karşıllı̆̆ında istisnai ceza tedbiri olarakölüm cezası (kurşuna dizilme) uygulanabilir. Kadınlar, suçu işlediği sırada on sekiz yaşını doldurmamış olan kişiler ve 65 yaşın üzerinde olan erkekler hakkında ölüm cezasına hükmedilemez".

1960 tarihli RSFSCCK, ilk başta 1926 tarihli RSFSCCK'ya oranla ölüm cezası gerektiren suçların kapsamını daraltmış, fakat zamanla ölüm cezası gerektiren suçların kapsamını genişletmiştir ${ }^{19}$. 60' 1 1 ve $70^{\prime}$ li yıllarda ölüm cezası öngörülen suçların sayısı artırılmış ve hatta bu suçların arasına çok büyük meblağda kamu malı üzerinde hırsızlık, çok büyük meblağda rüşvet alma, ıslah edici çalışma kurumlarında düzensizlik yaratma gibi suçlar eklenmiştir²0. Bunula birlikte 1961 ve 1989 yılları arasında ölüm cezasına mahkum olanların yüzde 96'sı nitelikli kasten öldürme suçları karşılığında olmuştur ${ }^{21}$.

1961 yılında 1980 kişi, 1962 yılında ise 2159 kişi ölüm cezasına mahkum edilmiştir. 1965 yılı sonrasında ise her yıl 379 ila 577 kişi arasında olmak üzere ölüm cezalarında hızlı düşüş yaşanmıştır ${ }^{22}$.

80 'li yılların sonunda ise ölüm cezasının daha da azaltılması yönünde bir tutum ortaya çıkmış ve malvarlığı ile ilgili suçlarda ölüm cezasından vazgeçilmiştir ${ }^{23}$. Örneğin 1981 yılında 415 kişi, 1985 yılında 407 kişi, 1989 yılında 100 kişi²4 $^{24} 1990$ yılında ise 223 kişi idam cezasına

19 KOMISSAROV, Vladimir / KRILOVA, Natalya / TYAJKOVA, İrina (Ed.), Ugolovnoye Pravo Rossiyskoy Federasii (Rusya Federasyonu Ceza Hukuku), Obşaya Çast (Genel Kısım), İzdatelstvo Statut, Moskva 2012, s.606.

20 PETRUHIN, http://ecsocman.hse.ru/data/423/343/1217/008pETRUHIN.pdf, s.83.

21 VASILEV, https://nbpublish.com/library_read_article.php?id=674.

22 VASILEV, https://nbpublish.com/library_read_article.php?id=674.

23 PETRUHİN, http://ecsocman.hse.ru/data/423/343/1217/008pETRUHIN.pdf, s.83.

24 BOYSOVA, Viktoriya, “Otnoşeniya k Smertnoy Kazni v Zarubejnıh Gosudarsv, Rosii i Soveta Evropı (Yabancı Devletlerin, Rusya'nın ve Avrupa Konseyi'nin Ölüm Cezasına Yaklaşımı)", Obşestvennıye Nauki i Sovremennost, No: 1, 2000, http://ecsocman.hse.ru/data/857/561/1216/005bOJCOWA.pdf, Erişim Tarihi: 28.3.2020, s.50, 
mahkum edilmiştir ${ }^{25}$. Zamanla ölüm cezasının öngörüldüğü suçlar daha da azalmıştır. 1993 yılında RSFSCCK'da ölüm cezası öngörülen sadece altı adet suç bulunmaktaydi ${ }^{26}$.

1990 yılından itibaren ölüm cezası uygulamasında daha da azalma yaşanmıştır. Resmi verilere göre, 1992 yılında 159 kişi ölüm cezasına mahkum edilmiş ve 18 mahkumun cezası infaz edilmiştir. 1993 yılında 157 kişi ölüm cezasına mahkum edilmiş ve 10 mahkumun cezası infaz edilmiştir. 1994 yılında 160 kişi ölüm cezasına mahkum edilmiş ve 10 mahkumun cezası infaz edilmiştir. 1995 yılında 141 kişi ölüm cezasına mahkum edilmiş ve 40 mahkumun cezası infaz edilmiştir. 1996 yılında ise 153 kişi ölüm cezasına mahkum edilmişş ve 53 mahkumun cezası infaz edilmiştir. ${ }^{28}$.

\section{1996 TARIHHLI RUSYA FEDERASYONU CEZA KANUNU}

12.12.1993 tarihli Rusya Federasyonu Anayasası'nın 20. maddesine göre, "1. Herkes yaşama hakkına sahiptir.

2. Ölüm cezası, bu ceza kaldırllıncaya kadar sanı̆ga davanın jüri katıllmıyla görülmesi hakkının tanınması suretiyle hayata karşı işlenen nitelikli ă̆ır suçlar karşılığında istisnai ceza tedbiri olarak federal kanunla konulabilir".

Anayasa uygun olarak hazırlanan ve 1.1.1997 tarihinde yürürlüğe giren 1996 tarihli RFCK'nın 59/1. maddesine göre, "1.Ölüm cezası istisnai ceza tedbiri olarak sadece hayata yönelmiş nitelikli ağır suçlara düzenlenebilir.

2. Kadınlara29, suçu işlediği sırada 18 yaşını doldurmamış olan kişilere ve hüküm sırasında 65 yaşını bitirmiş olan erkeklere ölüm cezası verilemez.

25 VASILEV, https://nbpublish.com/library_read_article.php?id=674.

26 PETRUHIN, http://ecsocman.hse.ru/data/423/343/1217/008pETRUHIN.pdf, s.83.

27 KOMISSAROV / KRILOVA / TYAJKOVA (Ed.), s.607.

28 KUDRYAVSEV, Vladimir / NAUMOV, Anatoliy / LUNEEV, Viktor, Ugolovnoye Pravo Rosii (Rusya Ceza Hukuku), Obşaya Çast (Genel Kısım), İzdatelstvo Yurist, Moskva 2006, s.386; PETRUHIN, http://ecsocman.hse.ru/data/423/343/1217/008pETRUHIN.pdf, s.85; Dönemin Rusya Federasyonu Devlet Başkanlığına Bağlı Bağışlama Komisyon Başkanı olan Pristavkin tarafından verilen bilgiye göre 1996 yılında 63 kişinin ölüm cezası infaz edilmiştir. (KOMISSAROV / KRILOVA / TYAJKOVA (Ed.), s.607.).

29 Bazı yazarlara göre, kadınlar bakımından ölüm cezasının yasaklanmasının anlaşılabilir bir yönü bulunmamaktadır. Çünkü ölüm cezasının bulunduğu ülkelerde, bu ceza sadece hamile kadınlar bakımından yasaklanmaktadır (DYADYUN, Kristina, “Smertnaya Kazn: Plyusı i Minusı v Sovremennom Obşestve (Ölüm Cezası: Modern Toplumda Artıları ve Eksileri)" Universum: Ekonomika i Yurisprudensiya, No: 7 
2.1 Ĕ̆er kişiyi iade eden yabancı devletin mevzuatı gereğince bu kişinin işlediği suça ölüm cezası öngörülmemişse veya ölüm cezasının uygulanmaması iade şartıysa ya da farklı sebeplerle ölüm cezası kişiye verilemiyorsa, yabancı devlet tarafindan karşılıklılık esasında uluslararası sözleşme gereğince cezai takibat için Rusya Federasyonu'na iade edilen kişiye ölüm cezası verilemez.

3. Ölüm cezası bağışlama suretiyle müebbet hapis veya yirmi beş sene hapis cezasına çevrilebilir".

Ceza Kanununda bu tanıma uyan beş adet suç bulunmaktadır. Bunlar, nitelikli kasten öldürme (m.105/2), kamu görevlisine suikast (m.277), yarg1 veya soruşturma görevlisine suikast (m.295), kolluk görevlisine suikast (m.317) ve soykırım (m.357) suçlarıdır. Kamu görevlisine, yargı veya soruşturma görevlisine ve kolluk görevlisine suikast suçlarının insan öldürme suçunun özel türleri olduğu dikkate alındığında mevzuatta ölüm cezasının sadece insan öldürme ve soykırım suçları karşılığında öngörüldüğü söylenebilir ${ }^{30}$.

Sözü geçen suçların hiçbirisinde ölüm cezası sabit ceza olarak öngörülmemiştir. Bu suçların hepsinde ölüm cezası seçimlik ceza olarak öngörülmüş olup, mahkemenin üst sınırdan ceza verebilmesi, olayda ağırlaştırıcı nedenlerin (m.63) bulunmasına ve daha hafif ceza verilmesini gerektiren bir nedenin (m.61) bulunmamasına bağlıdır ${ }^{31}$. Örneğin RFCK'nın 105/1. maddesine göre, nitelikli kasten öldürme ${ }^{32}$ suçunun cezası 8 seneden 20 seneye kadar hapis ve 1 seneden 2 seneye kadar özgürlüğün sınırlandırılması veya müebbet hapis veya ölüm cezasıdır.

Anayasa' da "kaldırılıncaya kadar" denilmek suretiyle ölüm cezasının geçici bir ceza olduğuna vurgu yapılmıştır. Sadece hayata karşı suçlar bakımından kabul edilmesi, herkese uygulanmaması ve seçimlik ceza

(18), 2015, http://7universum.com/ru/economy/archive/item/2314, Erişim Tarihi: 7.3.2020).

30 VASILEV, https://nbpublish.com/library_read_article.php?id=674.

31 STEPENKO, A. / NIKULİNA, O., "İsklyuçitelnıye Sluçai Primineniya Smertnoy Kazni (Ölüm Cezasının Uygulanmasında İstisnai Haller" Uçenıye Zametki TOGU, Tom 5 (Cilt 5), No: 4, 2014, http://pnu.edu.ru/media/ejournal/articles2014/TGU_5_212.pdf, 11.1.2020, s.405.

32 Kasten öldürme suçunun nitelikli hallerine suçun hamile kadına karşı işlenmesi, birden fazla kişiye karşı işlenmesi veya kan gütme saikiyle işlenmesi örnek olarak sayılabilir. 
olarak düzenlenmesi nedeniyle ölüm cezasının ceza kanununda istisnai bir ceza türü olarak öngörüldüğü söylenebilir ${ }^{33}$.

Ölüm cezasının infazı, 8.1.1997 tarihli Rusya Federasyonu Ceza İnfaz Kanunu'nda (RFCIK) düzenlenmiştir. Ölüm cezasına mahkum olan kimse, tek kişilik hücrede sıkı güvenlik ve tecrit şartlarında bulundurulur (RFCİK m.184/1). Ölüm cezasının infaz yöntemi, mahkumun halka kapalı ortamda kurşuna dizilmesidir (RFCIKK m.186/1).

Anayasanın 89/b. maddesi gereğince Devlet Başkanının mahkumların cezasını bağışlama yetkisi bulunmaktadır. Bu bağışlama yetkisi ölüm cezalarını da kapsamaktadır.

Ölüm cezası kesinleşmediği sürece infaz edilemez ${ }^{34}$. Ölüm cezasının kesinleşmesi halinde hükümlü bağışlanma talebiyle Devlet Başkanına başvurma hakkına sahiptir. Bu başvurunun yapılması halinde, Devlet Başkanı kararını açıklayıncaya kadar ölüm cezasının infazının durdurulmasina karar verilir (RFCIK m.184/2).

Daha önce de ifade edildiği üzere Rusya Federasyonu 28.02.1996 tarihinde Avrupa Konseyi'ne üye olmuştur ${ }^{35}$. Buna bağlı olarak 16.05.1996 tarih ve 724 sayılı Rusya'nın Avrupa Konseyi'ne Katılımıyla Bağlantılı Olarak Ölüm Cezası Uygulamasının Aşamalı Olarak Azaltılması Hakkında Devlet Başkanı Kararnamesi ${ }^{36}$ çıkartılarak Rusya Federasyonu'nda ölüm cezalarına fiili moratoryum ilan edilmiştir ${ }^{37}$. Bu Kararname dönemin Devlet Başkanı olan Boris Yeltsin tarafından çıkartılmıştır.

Moratoryumla birlikte ölüm cezalarının infazına son verilmiştir. Rusya Federasyonu'nda son ölüm cezası infazı 2.9.1996 tarihinde

33 ÇUÇAEV, Aleksandr / NIRKOVA, Natalya (Ed.), Ugolovnoye Pravo Rossii (Rusya Ceza Hukuku), Obşaya Çast (Genel Kısım), Uçebnik (Ders Kitabı), İzdatelstvo Feniks, Rostov-na-Donu 2009, s.373-374.

34 KOROLKOV A. (Ed.), Kommentariy k Ugolovnomu Kodeksu Rossiyskoy Federasii (Rusya Federasyonu Ceza Kanunu'nun Şerhi), İzdatelstvo EKSMO, Moskva 2004, s.170.

35 Rossiya v Sovete Evrop1 (Rusya Avrupa Konseyi'nde), https://www.mid.ru/rossia-vsovete-evropy, Erişim Tarihi: 22.3.2020.

$36 \quad$ 16.05.1996 tarih ve 724 sayılı Devlet Başkanı Kararnamesi için bkz. http://kremlin.ru/acts/bank/9357, Erişim Tarihi: 10.3.2020.

37 POBEYGALO, https://cyberleninka.ru/article/n/o-prestupnosti-v-rossii-i-problemesmertnoy-kazni-1, s.28. 
gerçekleşmiştir $^{38}$. Aslında bu dönemde mahkemeler ölüm cezasına hükmetmeye devam etmişlerdir ${ }^{39}$. 1997 yılında 106 kişi, 1998 yılında 116 kişi, 1999 yılında ise 19 kişi ölüm cezasına mahkum edilmiş, fakat hiçbir mahkumun cezası infaz edilmemiştir ${ }^{40}$. Bu dönemde Devlet Başkanı bağışlama yetkisini kullanmak suretiyle ölüm cezasına mahkum olan kişilerin cezasının infazına engel olmuştur ${ }^{41}$. Örneğin Devlet Başkanının 3.6.1999 tarih ve 698 sayılı Kararnamesi ile 703 mahkumun ölüm cezası bağışlanmıştır ${ }^{42}$. Yine 1998 tarihinde çıkarılan kararnamelerle ölüm cezasına mahkum edilen son 720 kişinin (bazı kaynaklara göre 713 veya 718 ) cezası bağışlanmıştır. Bunlardan 190 kişinin cezası 25 sene hapis cezasına, 530 kişinin cezası ise müebbet hapse çevrilmiştir ${ }^{43}$.

6 Numaralı Protokol, Rusya Federasyonu tarafından 16.04.1997 tarihinde imzalamıştır ${ }^{44}$. Fakat üç sene içerisinde onaylanması gerekirken, 6. Numaralı Protokol Federal Meclisin Devlet Duması tarafından bugüne kadar onaylanmamıştır. Aynı şekilde ölüm cezasının uygulanmaması yönünde moratoryum öngören kanun teklifleri de Devlet Duması tarafından kabul edilmemişlerdir ${ }^{45}$. Örneğin Devlet Başkanı Boris Yeltsin tarafından Devlet Dumasına sunulan Ölüm Cezasının İnfazına Moratoryum

38 DYADYUN, http://7universum.com/ru/economy/archive/item/2314.

39 PETRUHIN, http://ecsocman.hse.ru/data/423/343/1217/008pETRUHIN.pdf, s.85.

40 KOMISSAROV / KRILOVA / TYAJKOVA (Ed.), s.607.

41 MIHHLiN Aleksandr (Ed.), Ugolovnoye Pravo Rossiyskoy Federasii (Rusya Federasyonu Ceza Hukuku), Obşaya Çast (Genel Kısım), İzdatelstvo Yurist, Moskva 2004, s.286; PETRUHIN, http://ecsocman.hse.ru/data/423/343/1217/008pETRUHIN.pdf, s.85.

42 DYADYUN, http://7universum.com/ru/economy/archive/item/2314.

43 VASİLEV, https://nbpublish.com/library_read_article.php?id=674; Devlet Başkanının moratoryum öncesi 90'lı yıllarda ölüm cezalarını bağışladığına ilişkin örneklere rastlanmaktadır. Örneğin 1993 yılında 149 mahkumun, 1994 yılında 134 mahkumun, 1995 yılında ise 5 mahkumun ölüm cezası Devlet Başkanı tarafından bağışlanmıştır (BOYSOVA, http://ecsocman.hse.ru/data/857/561/1216/005bOJCOWA.pdf, s.50.).

44 TASS: 20 Let Bez Smernoy Kazni (Ölüm Ceza Olmadan 20 Sene), https://tass.ru/politika/3503703, Erişim Tarihi: 22.2.2020.

45 POBEYGALO, https://cyberleninka.ru/article/n/o-prestupnosti-v-rossii-i-problemesmertnoy-kazni-1, s.28. 
Hakkında Federal Kanun Teklifi, Devlet Duması tarafından 14.03.1997 tarihinde reddedilmiştir ${ }^{46}$.

Gerek Rusya Federasyonu Anayasası ve gerek Rusya Federasyonu Ceza Kanunu'nda sadece jüri katılımlı mahkemelerin ölüm cezası verebileceği hükme bağlanmıştır. Buna bağlı olarak Rusya Federasyonu Anayasa Mahkemesi 2.2.1999 tarih ve 3-P sayılı kararıyla Rusya Federasyonu Anayasası'nın 20. maddesinde öngörülen jüri katılımlı mahkemeler kuruluncaya kadar mahkemelerin ölüm cezası veremeyeceklerini karara bağlamıştır. 1999 yılında Rusya Federasyonu'nun sadece 9 federe unsurunda jüri katılımlı mahkemeler faaliyet göstermekte idi ${ }^{47}$. Anayasa Mahkemesi söz konusu kararında, ölüm cezasına hükmedilebilmesi için Rusya Federasyonu'nun belli bölgelerinde değil tüm bölgelerinde jüri katılımlı mahkemelerin kurulması gerektiğini, aksine bir tutumun eşitlik ilkesine aykırılık teşkil edeceğini ifade etmiştir ${ }^{48}$. Anayasa Mahkemesinin 1999 tarihli kararından günümüze kadar Rusya Federasyonu'nda ölüm cezası hem verilmemekte hem de uygulanmamaktadır ${ }^{49}$.

1.1.2010 tarihinde son bölge Çeçenistan Cumhuriyeti olmak üzere Rusya Federasyonu'nun tüm bölgelerinde jüri katılımlı mahkemeler faaliyete geçmişlerdir ${ }^{50}$. Fakat bu tarihten önce 29.10.2009 tarihinde Rusya Federasyonu Yüksek Mahkemesi ölüm cezasının uygulanabilirliği konusunda Rusya Federasyonu Anayasa Mahkemesine başvurmuştur ${ }^{51}$.

46 BOYSOVA, http://ecsocman.hse.ru/data/857/561/1216/005bOJCOWA.pdf, s.50; PETRUHIN, http://ecsocman.hse.ru/ data/423/343/1217/008pETRUHIN.pdf, s.85.

47 SIDORKIN, A., "Problemı Otmenı Smertnoy Kazni Skvoz Prizmu Obşih Prinsipov Prava (Hukukun Genel İlkeleri Bağlamında Ölüm Cezasının Kaldırılması Sorunu)", Vestnik RUDN, Seriya Yuridiçeskiye Nauki, No: 4, 2010, https://cyberleninka.ru/article/n/problema-otmeny-smertnoy-kazni-skvoz-prizmu-obschih-printsipovprava/viewer, Erişim Tarihi: 29.3.2020, s.29.

48 Rusya Federasyonu Anayasa Mahkemesinin 2.2.1999 tarih ve 3-P tarihli kararı için bkz. http://base.garant.ru/1351637/, Erişim Tarihi: 13.2.2020.

49 KOMISSAROV / KRILOVA / TYAJKOVA (Ed.), s.607.

50 POBEYGALO, https://cyberleninka.ru/article/n/o-prestupnosti-v-rossii-i-problemesmertnoy-kazni-1, s.29.

51 ZAGARINA, Anna, “Rossiya i Smernaya Kazn, Vmeste ili Prozn ... (Rusya ve Ölüm Cezası, Birlikte veya Ayrıca ...)" Vestnik Samarskoy Gumanitarnoy Akademii, Seriya: Pravo, No: 1 (7), 2010, https://cyberleninka.ru/article/n/rossiya-i-smertnayakazn-vmeste-ili-porozn/viewer, 29.03.2020, s.6. 
Rusya Federasyonu Anayasa Mahkemesi 19.11.2009 tarih ve 1344O-P sayılı kararıyla Anayasa'nın 20. maddesinde öngörülen jüri katılımlı mahkemeler kurulsa bile mahkemelerin ölüm cezası veremeyeceklerini karara bağlamıştır. Anayasa Mahkemesine göre, 6 Numaralı Protokol Rusya Federasyonu tarafından henüz onaylanmamış olsa bile Rusya Federasyonu Avrupa Konseyi üyeliğinden ayrıldığı yönünde resmi bir beyanda bulunmuş değildir. Başka bir ifadeyle Anayasa Mahkemesine göre, jüri katılımlı mahkemelerin ölüm cezasına hükmedebilmeleri için Rusya Federasyonu'nun Avrupa Konseyi üyeliğinden ayrılması gerekmekte$\operatorname{dir}^{52}$.

Bu kararla birlikte, Rusya Federasyonu Anayasa Mahkemesi 1999 tarihinde ilan ettiği ölüm cezasına hükmedilemeyeceği yönündeki moratoryumun uzatılmasına karar vermiştir. Doktrinde Anayasa Mahkemesinin kararının hukukilikten çok siyasi nitelikte olduğunu savunan yazarlar bulunmaktadir ${ }^{53}$.

Günümüzde Rusya Federasyonu'nda ölüm cezasını yasaklayan hukuk normunu Anayasa Mahkemesinin 19.11.2009 tarih ve 1344-O-P say1lı kararı oluşturmaktadır. ${ }^{54}$.

Uygulamada ölüm cezası bağışlanma suretiyle genellikle müebbet hapis cezasına çevrilmektedir. Devlet Başkanı tarafından 1998 yılında ölüm cezası bağışlanarak müebbet hapis cezasına çevrilen bir mahkum, 14 sene sonrasında anayasa ve ceza kanununda öngörülen "Mahkeme kararı olmaksızın hiç kimsenin özgürlüğünden yoksun bırakılamayacağı" ilkesinin ihlal edildiğini, ayrıca cezasının daha ağır bir cezaya çevrildiğini ve dolayısıyla Avrupa İnsan Hakları Sözleşmesi'nin 7. maddesinin ${ }^{55}$ ihlal edildiğini ileri sürerek bağışlama kararının hukuka aykırı olduğu

52 Rusya Federasyonu Anayasa Mahkemesinin 19.11.2009 tarih ve 1344-O-P sayılı kararı için bkz. http://www.consultant.ru/document/cons_doc_LAW_94045/a35423ae3af202fcc4ee35270a172417854d0260/, Erişim Tarihi: 13.2.2020.

53 POBEYGALO, https://cyberleninka.ru/article/n/o-prestupnosti-v-rossii-i-problemesmertnoy-kazni-1, s.29.

54 DYADYUN, http://7universum.com/ru/economy/archive/item/2314.

55 4.11.1950 tarihli Avrupa İnsan Hakları Sözleşmesi'nin “Kanunsuz Ceza Olmaz İlkesi" başlıklı 7. maddesine göre, "Hiç kimse işlendiği zaman ulusal veya uluslararası hukuka göre bir suç sayılmayan bir fiil veya ihmalden dolayı mahkum edilemez. Yine hiç kimseye, suçun işlendiği sırada uygulanabilecek olan cezadan daha ă̆ır bir ceza verilemez." 
iddiasıyla Rusya Federasyonu Yüksek Mahkemesine başvurmuştur. Ancak Yüksek Mahkeme, mahkumun Devlet Başkanının kararına karşı dava açma süresini geçirdiğini ve ayrıca mahkum hakkında cezanın mahkeme tarafından verildiğini, Devlet Başkanının hümanizm ilkesinden yola çıkarak yasal bağışlama yetkisini kullandığını, cezanın ağırlaştığından söz edilmeyeceğini ifade ederek bu talebin reddine karar vermiştir ${ }^{56}$.

\section{SONUÇ}

Son yıllarda modern ceza kanunlarında ölüm cezası uygulamasına son verildiği ve ölüm cezasının genellikle baskıcı ceza kanununa sahip olan gelişmemiş ülkelerde bulunduğu görülmektedir.

Avrupa Konseyi'ne üye olmakla birlikte ölüm cezası sorununun Rusya Federasyonu'nda kesin bir çözüme kavuşturulmadığ görülmektedir. Rusya Federasyonu Anayasa Mahkemesinin 19.11.2009 tarih ve 1344O-P sayılı kararının ölüm cezasının geçici olarak durdurmaya yönelik olduğu söylenebilir. Ayrıca Anayasa Mahkemesinin kararında ölüm cezası tamamen yasaklanmış olmayıp, ölüm cezasının uygulanabilirliği Rusya Federasyonu'nun Avrupa Konseyi üyeliğinin devam edip etmemesine bağlı tutulmuştur. Bu durum, Rusya Federasyonu'nun Avrupa Konseyi üyeliğinden ayrılması durumunda mahkemelerin ölüm cezası kararları vermesine imkan tanımaktadır.

Ölüm cezasının kaldırılıp kaldırılmayacağına yönelik tercihin yasama organına ait olduğu ortadadır. Rusya Federasyonu'nda ölüm cezası sorununun çözülememesinin sebebi daha çok yürütme değil, bu konuda konusunda kararlılık gösteremeyen kanun koyucunun tutumundan kaynaklanmaktadır ${ }^{57}$. Günümüzün Rusya Federasyonu Devlet Başkanı olan Vladimir Putin de çok kez ölüm cezasına karşı olduğunu ifade etmiştir. Buna karşılık Federal Meclisin Devlet Duması tam tersine Devlet

$56 \quad$ PRAVO.RU Novosti (Haberler) 20.05.2011: Prigoverenniy k Smernoy Kazni Osporil v Verhovnıy Sud Ukaz o Svoem Pomilovanii Kak Negumannıy (Ölüm Cezası Mahkumu Kendisinin Bağışlanması Hakkındaki Kararnameyi “İnsancıl Olmadığı” İddiasıyla Yüksek Mahkemede Tartışmaya Açtı), https://pravo.ru/news/view/54350/, Erişim Tarihi: 1.3.2020.

57 POBEYGALO, https://cyberleninka.ru/article/n/o-prestupnosti-v-rossii-i-problemesmertnoy-kazni-1, s.29. 
Başkanından ölüm cezası konusundaki moratoryumun kaldırılmasını talep etmiştir ${ }^{58}$.

Önemle ifade etmek gerekir ki, Rusya Federasyonu barış zamanında ölüm cezasını yasaklayan Avrupa İnsan Hakları Sözleşmesi'ne Ek 6 Numaralı Protokolü imzalamakla birlikte, bu ceza türünü her dönemde yasaklayan Avrupa İnsan Hakları Sözleşmesi'ne Ek 13 Numaralı Protokolü imzalamış değildir. Rusya Federasyonu Anayasa Mahkemesinin 19.11.2009 tarih ve 1344-O-P sayılı kararında da savaş zamanında ölüm cezasının uygulanabilirliği konusunda bir tartışma yapılmış değildir. Bu durum Rusya Federasyonu'nda savaş zamanında ölüm cezasının uygulanmasının yolunu açmaktadır. 


\section{KAYNAKLAR}

BOYSOVA, Viktoriya, “Otnoşeniya k Smertnoy Kazni v Zarubejnıh Gosudarsv, Rosii i Soveta Evropı (Yabanc1 Devletlerin, Rusya'nın ve Avrupa Konseyi'nin Ölüm Cezasına Yaklaşımı)", Obşestvennıye Nauki i Sovremennost, No: 1, 2000, http://ecsocman.hse.ru/data/857/561/1216/005bOJCOWA.pdf, Erişim Tarihi: 28.3.2020.

ÇUÇAEV, Aleksandr / NIRKOVA, Natalya (Ed.), Ugolovnoye Pravo Rossii (Rusya Ceza Hukuku), Obşaya Çast (Genel Kısım), Uçebnik (Ders Kitab1), İzdatelstvo Feniks, Rostov-na-Donu 2009.

DÖNMEZER, Sulhi / ERMAN, Sahir, Nazari ve Tatbiki Ceza Hukuku, Genel Kısım, Cilt II, 11. Bası, Beta Yayınları, İstanbul 1999.

DYADYUN, Kristina, “Smertnaya Kazn: Plyusı i Minusı v Sovremennom Obşestve (Ölüm Cezası: Modern Toplumda Artıları ve Eksileri)" Universum: Ekonomika i Yurisprudensiya, No: 7 (18), 2015, http://7universum.com/ru/economy/archive/item/2314, Erişim Tarihi: 7.3.2020.

KOMISSAROV, Vladimir / KRILOVA, Natalya / TYAJKOVA, İrina (Ed.), Ugolovnoye Pravo Rossiyskoy Federasii (Rusya Federasyonu Ceza Hukuku), Obşaya Çast (Genel Kısım), İzdatelstvo Statut, Moskva 2012.

KOROLKOV A. (Ed.), Kommentariy k Ugolovnomu Kodeksu Rossiyskoy Federasii (Rusya Federasyonu Ceza Kanunu'nun Şerhi), İzdatelstvo EKSMO, Moskva 2004.

KOZAÇENKO, İvan / NEZNAMOVA, Zinaida (Ed.), Ugolovnoye Pravo (Ceza Hukuku), Obşaya Çast (Genel Kısım), İzdatelstvo İnfra.MNorma, Moskva 1997.

KOZAÇENKO, İvan / NOVOSELOV, Gennadiy, Ulolovnoye Pravo (Ceza Hukuku), Obşaya Çast (Genel Kısım), İzdatelstvo Yurayt, Moskva 2018.

KUDRYAVSEV, Vladimir / NAUMOV, Anatoliy / LUNEEV, Viktor, Ugolovnoye Pravo Rosii (Rusya Ceza Hukuku), Obşaya Çast (Genel Kısım), İzdatelstvo Yurist, Moskva 2006. 
KUZNESOVA, Ninel / TYAJKOVA, İrina (Ed.), Kurs Ugolovnogo Prava (Ceza Hukuku Dersleri), Obşaya Çast (Genel Kısım), Uçeniya o Prestuplenii (Suç Hakkında), Tom 1 (1. Cilt), İzdatelstvo Zersalo, Moskva 2002.

MïHLIN Aleksandr (Ed.), Ugolovnoye Pravo Rossiyskoy Federasii (Rusya Federasyonu Ceza Hukuku), Obşaya Çast (Genel Kısım), İzdatelstvo Yurist, Moskva 2004.

NAUMOV, Anatoliy, Rusya Cinayet Hüququ, Ümumi Hisse, (Tercüme: Qurbanov H.), Qanun Neşriyyatı, Bakı 1998.

ÖNDER, Ayhan, Ceza Hukuku Dersleri, Filiz Kitabevi, İstanbul 1992. PETRUHIN, İgor, “Pravo Na Jizn i Smertnaya Kazn (Yaşam Hakkı ve Ölüm Cezası)", Obşestvennıye Nauki i Sovremennost, No: 5, 1999, http://ecsocman.hse.ru/data/423/343/1217/008pETRUHIN.pdf, Erişim Tarihi: 9.1.2020.

POBEYGALO, Eduard, “O Prestupnosti v Rosii i Problema Smertnoy Kazni (Rusya'da Suç ve Ölüm Cezası Problemi Hakkında)", Evraziyskiy Forum, No: 1 (2), 2010, https://cyberleninka.ru/article/n/o-prestupnosti-v-rossii-i-probleme-smertnoy-kazni-1, Erişim Tarihi: 12.2.2020.

PRAVO.RU Novosti (Haberler) 20.05.2011: Prigoverenniy k Smernoy Kazni Osporil v Verhovnıy Sud Ukaz o Svoem Pomilovanii Kak Negumannıy (Ölüm Cezası Mahkumu Kendisinin Bağışlanması Hakkındaki Kararnameyi "İnsancıl Olmadığı" İddiasıyla Yüksek Mahkemede Tartışmaya Açtı), https://pravo.ru/news/view/54350/, Erişim Tarihi: 1.3.2020.

Rusya Federasyonu Anayasa Mahkemesinin 2.2.1999 Tarih ve 3-P Tarihli Karar1, http://base.garant.ru/1351637/, Erişim Tarihi: 13.2.2020.

Rusya Federasyonu Anayasa Mahkemesinin 19.11.2009 Tarih ve 1344-OP Sayılı Kararı, http://www.consultant.ru/document/cons_doc_LAW_94045/a35423ae3af202fcc4ee35270a17241 7854d0260/, Erişim Tarihi: 13.2.2020.

Rusya Federasyonu Devlet Başkanlığının Resmi Web Sitesi, http://kremlin.ru, 10.3.2020. 
Rusya Federasyonu Dişişleri Bakanlığının Resmi Web Sitesi https://www.mid.ru, 29.3.2020.

SİDORKİN, A., "Problemı Otmenı Smertnoy Kazni Skvoz Prizmu Obşih Prinsipov Prava (Hukukun Genel İlkeleri Bağlamında Ölüm Cezasının Kaldırılması Sorunu)", Vestnik RUDN, Seriya Yuridiçeskiye Nauki, No: 4, 2010, https://cyberleninka.ru/article/n/problema-otmeny-smertnoy-kazni-skvoz-prizmu-obschih-printsipov-prava/viewer, Erişim Tarihi: 29.3.2020.

STEPENKO, A. / NIKULINAA, O., “İsklyuçitelnıye Sluçai Primineniya Smertnoy Kazni (Ölüm Cezasının Uygulanmasında İstisnai Haller" Uçenıye Zametki TOGU, Tom 5 (Cilt 5), No: 4, 2014, http://pnu.edu.ru/media/ejournal/articles-2014/TGU_5_212.pdf, 11.1.2020.

TASS: 20 Let Bez Smernoy Kazni (Ölüm Ceza Olmadan 20 Sene), https://tass.ru/politika/3503703, Erişim Tarihi: 22.2.2020.

VASİLEV, Aleksey, “Smernaya Kazn v Rosii: Vısşaya, İsklyuçitelnaya Mera Nakazaniya, Ustraşeniya ili Politika? (Rusya'da Ölüm Cezası: Yüksek, İstisnai Ceza Tedbiri, Gözdağı mı? Siyaset mi?)", No: 4, 2013, https://nbpublish.com/library_read_article.php?id=674, Erişim Tarihi: 22.02.2020.

ZAGARINA, Anna, "Rossiya i Smernaya Kazn, Vmeste ili Prozn ... (Rusya ve Ölüm Cezası, Birlikte veya Ayrıca ...)" Vestnik Samarskoy Gumanitarnoy Akademii, Seriya: Pravo, No: 1 (7), 2010, https://cyberleninka.ru/article/n/rossiya-i-smertnaya-kaznvmeste-ili-porozn/viewer, 29.03.2020. 